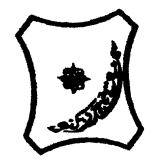

Bayero Journal of Pure and Applied Sciences, 12(1):328 - 336

ISSN 2006 - 6996

\title{
SEROLOGICAL SURVEY OF IMMUNOGLOBULIN G ANTIBODY AMONG DIFFERENT POPULATIONS WITH ASSYMTOMATIC SHEDDING OF GENITAL HERPES IN KATSINA STATE
}

\author{
${ }^{1 *}$ Hayatudeen, M.R., ${ }^{2}$ Aminu, M., ${ }^{2}$ Inabo, H.I., ${ }^{1}$ Bashir, A., ${ }^{3}$ Abdullahi, S., ${ }^{4}$ Ali, Saleh \\ and ${ }^{5}$ Tahir, $M$.
}

1. Department of Microbiology, Faculty of Sciences, Umaru Musa Yar adua University, Katsina.

2. Department of Microbiology. Faculty of Science, Ahmadu Bello University, Zaria

3. Department of Pharmacology, Faculty of Medicine, Umaru Musa Yar adua University, Katsina

4. National Root Crop Research Institute, Umudike, Abia State

5. Department of Medical laboratory Science, Faculty of Allied Health Sciences, Ahmadu Bello University, Zaria.

Correspondence author: hayatudeen.muhammad@umyu.edu.ng (+2348138652564)

\section{ABSTRACT}

Herpes Simplex Virus type 2 (HSV-2) is a significant public health problem being one of the most prevalent sexually transmitted infections worldwide and the leading cause of genital ulcerative disease that is common both in industrialized and developing countries. Therefore, a study on the serological survey of Immunoglobulins $G$ antibody among different populations with asymptomatic shedding of genital herpes in Katsina State, north-western Nigeria was carried out. A total of 460 (86 HIV, 136 feverish patients, 125 pregnant women and 113 normal Individuals) blood samples were collected from six hospitals located across the three senatorial zones of the State. The serum was separated from the blood and used for the analysis. The participant's socio-demographic information and clinical presentations were also noted with the aid of a questionnaire. Viral antibodies were detected by HSV-2 IgG ELISA Kits. The HSV-2 IgG was detected in $72.8 \%$ of the serum tested. The prevalence among patients presenting with fever was $70.6 \%$, and it was $74.4 \%$ in the pregnant women. The prevalence in HIV positive patients was $75.6 \%$ while it was $73.5 \%$ in the apparently healthy individuals. There was a significant association between HIV positivity, feverish condition and HSV-2 prevalence. Higher prevalence was recorded at General Hospital Dutsinma $89.6 \%$ and there was a statistically significant association between prevalence and hospital studied. Generally, older participants were more vulnerable to HSV-2 infection than younger ones. There was no statistical significant association between sex of the participants and HSV2 infection. None of the sociodemographic factors was significant/y associated with HSV2 infection except marital status. There was no significant association between socioeconomic status, sexual activity, use of protection, number of sexual partners, clinical manifestation, level of education, and occupation of the participants with HSV-2 infection. The present study indicates that prevalence of HSV-2 appears to be relatively high and older participants were more vulnerable to HSV-2 infection in Katsina State. There is need for educating populace on HSV-2 infection and its mode of transmission to reduce the level of its spread between individuals in the population.

Keywords: HSV-2; IgG; Genital; Serum; Antibody

\section{INTRODUCTION}

Herpes simplex virus type- 2 is the most common cause of genital herpes (Looker et al., 2008). The disease is manifested by macules and papules followed by vesicles, pustules, and ulcers (Hadeel et al., 2015). In males, primary infection leads to a cluster of vesicular lesions on erythematous bases on the glans or shaft of the penis (Tobian et al., 2009). In females, painful lesions occur bilaterally on the vulva and cervicitis occurs in $90 \%$ of women (Martin et al., 2009). Headache, fever, depression and inguinal lymphadenopathy are often systemic signs and symptoms of genital herpes infection (Brook et al., 2010). Genital lesions due to herpes are often very painful, and can lead to substantial psychological morbidity (Stanberry et al., 2000). The virus can also be passed from mother to child during birth resulting to the neonatal infection that is very serious. Without treatment, $80 \%$ of infants with disseminated disease die, and those who do survive are often have damaged brain (Tyler, 2004). Majority of the infections are asymptomatic and this enhances HSV-2 transmission because 
Special Conference Edition, November, 2019 asymptomatic individuals shed the virus and However, the large majority of persons with genital herpes do not know they have the disease and infection and reactivation are typically asymptomatic. This typical asymptomatic nature of genital herpes facilitates its spread in the population, genital herpes is associated with considerable morbidity and even mortality (Tobian et al., 2009). The virus annually affects an estimate of 417 million persons in the reproductive age range worldwide (WHO, 2015).

\section{MATERIAL AND METHODS \\ Study Area}

The study was carried out in Katsina State located at the extreme northern margin of Nigeria. The State covers a total area of about $23,938 \mathrm{sqkm}(3,370 \mathrm{sq})$ with a total population of $5,801,584$ people, going by 2006 census (FGN, 2007). It lies between latitudes $11^{\circ} 08^{\prime} \mathrm{N}$ and $13^{\circ} 22^{\prime} \mathrm{N}$ and longitudes $6^{\circ} 52^{\prime} \mathrm{E}$ and $9^{\circ} 20^{\prime} \mathrm{E}$. The State has thirty four (34) local government areas which are divided into three (3) senatorial zones according to their geographical locations namely; Funtua zone, Katsina zone and Daura zone (Dauda et al., 2011).

\section{Study Design and Population}

The study was a descriptive cross-sectional and study population comprised of males and females among HIV patients, pregnant women, feverish patients and apparently healthy individuals. The hospitals selected for the study were; General Hospital Funtua, Children's and Maternity Hospital Malumfashi, General Hospital Dutsinma, General Hospital Katsina, General Hospital Daura, General Hospital Baure.

\section{Ethical Approval and Consent}

Ethical approval was obtained from the Ethical Committee of General Hospital Services Management Board, Katsina State. Consent form was obtained from patients prior to enrolment in the study. transmit the disease (Phipp et al., 2015).

\section{Blood Sample Collection}

A total of 460 blood samples were collected aseptically using $5 \mathrm{ml}$ syringe from patients who gave consent by the laboratory technologist in the selected hospitals of Katsina State. The whole blood was allowed to clot for 30 minutes and centrifuged at $1000 \mathrm{rmp}$ for 10 minutes. The serum was carefully removed with a transfer pipette and transferred aseptically to a sterile labeled serum storage screw-capped container and stored at $-20^{\circ} \mathrm{C}$ in a freezer until analyzed.

\section{Serological Assay for HSV-2 IgM Antibody}

The serum samples were analyzed using HSV-2 IgM specific ELISA kits manufactured by Diagnostic Automation / Cortez Diagnostics Inc, USA. The manufacturer's instructions were strictly followed.

\section{RESULTS}

A total of 460 participants over 10 year of age from four different populations were recruited for the study with different characteristics (Table 1). This include $86(18.7 \%)$ HIV patients, 136 (29.6\%) feverish patients, 113 (24.6\%) apparently healthy individuals and 125 (27.2\%) pregnant women. Among the participants, 258 (56.1\%) were females and 202 (43.9\%) were males.

Of the 460 sera analysed, $72.8 \%$ were positive for IgG. The higher prevalence rates was seen HIV $75.6 \%$ participants while least was observed among patients presenting with fever were $70.6 \%$. while IgG prevalence rates among HIV positives patients were $75.6 \%$. There was an association between feverish condition and HIV positivity with HSV-2 infection (Table 2). Analysis of the results by hospital showed that higher prevalence rate of $89.6 \%$ was recorded in General Hospital Dutsinma while the least was recorded in General Hospital Baure (53.1\%: 34/64). There was a significant association between prevalence and the hospitals $\left(X^{2}=\right.$ 25.415, $d f=5, p=0.003$ ) (Table 3). 
Special Conference Edition, November, 2019

Table 1: General characteristics of the participants in Katsina State, Nigeria

\begin{tabular}{lcc}
\hline Parameter & Frequency & Percent (\%) \\
\hline Age Group (Years) & 75 & \\
$10-20$ & 163 & 16.3 \\
$21-30$ & 142 & 35.4 \\
$31-40$ & 58 & 30.9 \\
$41-50$ & 22 & 12.6 \\
51 and above & & 4.8 \\
Socioeconomic Status & 280 & 32.5 \\
Low & 180 & 67.5 \\
High & & \\
Marital Status & 279 & 60.7 \\
Married & 158 & 34.3 \\
Single & 18 & 3.9 \\
Divorced & 5 & 1.1 \\
Widowed & & \\
Level of Education & 121 & 26.3 \\
Tertiary & 138 & 30.0 \\
Secondary & 107 & 23.3 \\
Primary & 94 & 20.4 \\
None & & \\
Occupation & 137 & 29.8 \\
Civil servant & 65 & 14.1 \\
Farmer & 118 & 25.7 \\
Self-employed & 140 & 30.4 \\
Unemployed & & \\
Gender & 257 & 55.9 \\
Female & 203 & 44.1 \\
Male & & \\
\hline
\end{tabular}

Table 1: Prevalence of genital herpes according to participant's category among different populations in Katsina State, Nigeria

\begin{tabular}{lllll}
\hline Category & Total & \multicolumn{3}{c}{ Immunoglobulin G } \\
\cline { 3 - 5 } & & Positive (\%) & Negative (\%) & P-value \\
\hline HIV Patients & 86 & $65(75.6)$ & $21(24.4)$ & 0.030 \\
Fever Patients & 136 & $96(70.6)$ & $40(29.4)$ & 0.002 \\
Pregnant Women & 125 & $93(74.4)$ & $32(25.6)$ & 0.432 \\
Healthy Persons & 113 & $81(73.5)$ & $32(28.3)$ & 0.213 \\
\hline Total & $\mathbf{4 6 0}$ & $\mathbf{3 3 5 ( 7 2 . 8 )}$ & & \\
\hline
\end{tabular}

Table 2: Prevalence rate of genital herpes among different populations by hospital in Katsina State, Nigeria

\begin{tabular}{lllll}
\hline Hospital & Total & \multicolumn{3}{c}{ Immunoglobulin G } \\
\cline { 3 - 5 } & & Positives (\%) & Negatives (\%) & P-value \\
\hline GH Dutsinma & 67 & $60(89.6)$ & $07(10.4)$ & 0.003 \\
GH Katsina & 88 & $65(73.9)$ & $23(26.1)$ & \\
GH Baure & 64 & $34(53.1)$ & $30(46.9)$ & \\
GH Daura & 86 & $63(73.3)$ & $23(26.7)$ & \\
GH Funtua & 74 & $59(79.7)$ & $15(20.3)$ & \\
MCH Malumfashi & 81 & $54(66.7)$ & $27(33.3)$ & \\
\hline Total & $\mathbf{4 6 0}$ & $\mathbf{3 3 5 ( 7 2 . 8 )}$ & $\mathbf{1 2 5}(\mathbf{2 7 . 2})$ & \\
\hline
\end{tabular}

Key: $\mathrm{GH}=$ General Hospital; $\mathrm{MCH}=$ Maternal and Children Hospital

Analysis of the results according to Senatorial District showed higher prevalence rate of $81.3 \%$ in Katsina Central while Katsina North had the least $64.7 \%$. There was a statistical significant association between prevalence and Senatorial Districts $\left(x^{2}=9.835, d . f=2, p=0.007\right)$. Analysis of the results according to age groups is shown in Table 5. Higher prevalence was recorded among participants in age group 41-50 years $84.5 \%$ while participants in age group $16-20$ years had the lowest $64.0 \%$. 
Special Conference Edition, November, 2019

There was no significant association between age of the participants and prevalence $\left(X^{2}=\right.$ 10.386, $d f=4, p=0.239$ ). The results were analysed by sex as shown in Table 6 . Although there was no significant association between sex of the participants and HSV-2 prevalence $\left(X^{2}=\right.$ $0.150, d f=1, p=0.314$ ), however, females had higher prevalence $73.5 \%$ compared to males $71.9 \%$ and however, male participants were two times more likely to be infected than females $(\mathrm{OR}=2.017,95 \%$ C.I $=0.397-5.730)$.

The data and results were analysed according to socio-demographic factors as shown in Table 7. Higher prevalence of $77.7 \%$ was detected among those with high socio-economic status while those with low socio-economic status had lower prevalence rates of $69.8 \%$. There was no statistically significant association between socio-economic status and HSV-2 prevalence $\left(x^{2}=3.341, d f=1, p=0.063\right)$. However those with high socio-economic status were two times more likely to be infected with the virus compared to those with low socio-economic status (OR=2.007, 95\% C.I=0.321-5.210).

The higher prevalence rates of $76.3 \%$ were recorded among uneducated participants while those with secondary school level had the lowest of $70.1 \%$. Similarly, there was no statistically significant association between educational level and HSV-2 prevalence $\left(\mathrm{X}^{2}=1.847, \mathrm{df}=3, \mathrm{p}=\right.$ $0.605)$. Analysis of the results by occupation showed that civil servants had higher prevalence rate of $78.4 \%$ while lower rate of $60.0 \%$ was obtained among farmers. There was no statistically significant association between occupation and HSV-2 prevalence $\left(X^{2}=6.791\right.$, $\mathrm{df}=3, \mathrm{p}=0.079$ ).

The data and results when analysed according to marital status of the participants showed that the divorced had higher prevalence rate of $80.0 \%$ while lowest of $66.7 \%$ was obtained among widows. There was no statistically significant association between HSV-2 prevalence and marital status $\left(X^{2}=2.601, d f=3\right.$, $p=0.046)$.

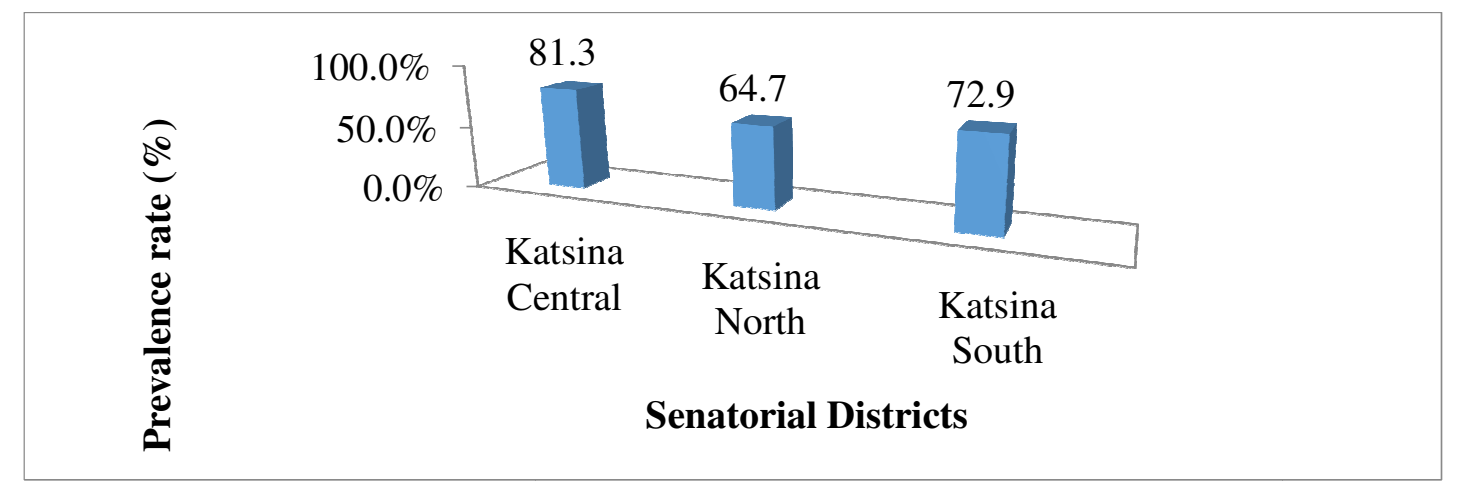

Figure 1: Prevalence rate of genital herpes in relation to senatorial district of Katsina State, Nigeria

Table 3: Prevalence of genital herpes in relation to age of participant in Katsina State, Nigeria

\begin{tabular}{lllll}
\hline Age group & Total & \multicolumn{3}{c}{ Immunoglobulin G } \\
\cline { 3 - 5 } & & Positives (\%) & Negative (\%) & P-value \\
\hline $10-20$ & 75 & $48(64.0)$ & $27(36.0)$ & 0.239 \\
$21-30$ & 163 & $113(69.3)$ & $50(30.7)$ & \\
$31-40$ & 142 & $107(75.4)$ & $35(24.6)$ & \\
$41-50$ & 58 & $49(84.5)$ & $09(15.5)$ & \\
51 and above & 22 & $18(81.8)$ & $04(18.2)$ & \\
\hline Total & $\mathbf{4 6 0}$ & $\mathbf{3 3 5 ( 7 2 . 8 )}$ & $\mathbf{1 2 5}(\mathbf{2 7 . 2})$ & \\
\hline
\end{tabular}

Table 4: Prevalence of genital herpes in relation to gender among different populations in Katsina State, Nigeria

\begin{tabular}{llllll}
\hline Gender & Total & \multicolumn{4}{c}{ Immunoglobulin G } \\
\cline { 3 - 5 } & & $\begin{array}{l}\text { Positives } \\
(\%)\end{array}$ & $\begin{array}{l}\text { Negatives } \\
(\%)\end{array}$ & P-value & Odd Ratio \\
\hline Male & 203 & $146(71.9)$ & $57(28.1)$ & 0.314 & 0.065 \\
Female & 257 & $189(73.5)$ & $68(26.5)$ & \\
\hline Total & $\mathbf{4 6 0}$ & $\mathbf{3 3 5 ( 7 2 . 8 )}$ & $\mathbf{1 2 5 ( 2 7 . 2 )}$ & \\
\hline
\end{tabular}


Special Conference Edition, November, 2019

Table 5: Prevalence of genital herpes in relation to socio-demographic factors

\begin{tabular}{lllll}
\hline Factors & Total & \multicolumn{3}{c}{ Immunoglobulin G } \\
\cline { 3 - 5 } & & Positives (\%) & Negative (\%) & P-value \\
\hline Socio-economic & & $139(77.7)$ & $41(22.3)$ & 0.063 \\
High & 180 & $196(69.8)$ & $84(30.2)$ & \\
Low & 280 & $71(76.3)$ & $30(21.6)$ & 0.605 \\
Education & & $76(70.4)$ & $35(37.8)$ & \\
None & 93 & $96(70.1)$ & $44(27.1)$ & \\
Primary & 108 & $92(75.4)$ & $22(40.0)$ & \\
Secondary & 137 & & & \\
Tertiary & 122 & $109(78.4)$ & $30(21.6)$ & 0.779 \\
Occupation & & $91(72.2)$ & $35(37.8)$ & \\
Civil servant & 139 & $102(72.9)$ & $44(27.1)$ & \\
Self employed & 126 & $33(60.0)$ & $22(40.0)$ & \\
Unemployed & 146 & & & \\
Farmer & 55 & $109(69.4)$ & $48(30.6)$ & 0.046 \\
Marital status & & $210(75.0)$ & $70(25.0)$ & \\
Single & 157 & $12(66.7)$ & $06(33.3)$ & \\
Married & 280 & $4(80.0)$ & $01(20.0)$ & \\
Widow & 18 & &
\end{tabular}

Analysis of data and results according to possible risk factors that might predispose to the infection is shown in Table 8 . Majority $73.4 \%$ of the participants that claimed not to be involved in any sexual activity had higher prevalence compared to those that claimed to be involved $72.5 \%$. There was no statistically significant association between sexual activity and HSV-2 prevalence $\left(x^{2}=0.033, d f=1, p=0.856\right)$. However, those who claimed to be involved in sexual activity were 1.1 times more likely to be infected than those that claimed not to be involved (OR=1.067, 95\% C.I=1.004-2.730). The participants who claimed to have single sexual partner had a lower prevalence rate $70.9 \%$ compared to those who claimed to have more than one sexual partner $74.1 \%$. There was no significant association between sexual partner and HSV-2 prevalence $\left(x^{2}=0.433, d f=\right.$ $1, p=0.511)$. However, those with more than one sexual partner were almost two times more likely to be infected than those with single sexual partner $(O R=1.789,95 \%$ C.I $=1.970$ 3.412). The participants who claimed to use protection had higher prevalence rate $(74.0 \%)$ compared to those who did not claim to use any protection $(72.3 \%)$. There was no statistically significant association between the use of protection and HSV-2 prevalence $\left(X^{2}=1.116\right.$, $\mathrm{df}=1, \mathrm{p}=0.734)$. However, those who claimed to use protection were almost 1.0 times more likely to be infected than those did not claimed $(\mathrm{OR}=1.004,95 \%$ C. $\mathrm{I}=0.121-3.000)$.

Table 6: Prevalence rate of genital herpes in relation to risk factors among different population in Katsina State, Nigeria

\begin{tabular}{llllll}
\hline Variables & Total & \multicolumn{4}{c}{ IgM } \\
\cline { 3 - 5 } & & Positive (\%) & $\begin{array}{l}\text { Negative } \\
(\%)\end{array}$ & P-value & Odd ratio \\
\hline $\begin{array}{l}\text { Sexual } \\
\text { active }\end{array}$ & 335 & $243(72.5)$ & $92(27.5)$ & 0.856 & 0.872 \\
$\begin{array}{l}\text { Yes } \\
\text { No }\end{array}$ & 124 & $91(73.4)$ & $33(26.6)$ & & \\
$\begin{array}{l}\text { Partners } \\
\text { Yes }\end{array}$ & 165 & $117(70.9)$ & $48(29.1)$ & 0.511 & 1.012 \\
$\begin{array}{l}\text { No } \\
\text { Protection }\end{array}$ & 170 & $126(74.1)$ & $44(25.9)$ & & \\
$\begin{array}{l}\text { Yes } \\
\text { No }\end{array}$ & 123 & $91(74.0)$ & $32(26.0)$ & 0.734 & 0.933 \\
\hline
\end{tabular}




\section{Special Conference Edition, November, 2019 DISCUSSION}

Infection with HSV-2 has been shown to occur mostly among sexually-active individuals (Kahsay et al., 2015) and majority of the participants recruited in this study were sexually active. In addition, HSV-2 is known to establish lifelong infection that recurs more often and detecting antibodies to the virus is often used to identify carriers of HSV-2 (Rathore et al., 2010; Soumyabrata et al., 2015). Hence, these infected patients are carriers of HSV-2 and might continue to be source of the virus in the community.

In this study, the higher prevalence of $72.8 \%$ found is lower than the $97.2 \%$ reported in Portacourt, Nigeria (Okonko et al., 2015) and the $96.5 \%$ in Coitdevoire (Boni et al., 2015) but similar to the $73.8 \%$ reported in Enugu, Nigeria (Ojinmah et al., 2012), 73.0\% in South Africa (Abbai et al., 2015).

The high prevalence observed in this study may probably be due to population at risk of acquiring HSV-2 infection involved in this study. The populations included feverish pateints, HIVpositive patients and pregnant women. Fever has been shown to be a sign of HSV-2 infection (Aminu et al., 2014) and pregnancy can serve as a factor that reactivates HSV-2 from its latent state (Edith et al., 2014). In addition, HIV and HSV-2 act synergetically and HIV cases are found to be high in sub-saharan Africa and infection with HSV-2 has been shown to facilitate HIV transmission (Mawak et al., 2009) and increase the risk of HIV acquisition (Schiffer et al., 2014). These HSV-2 infected patients might therefore be at greater risk of HIV infection.

In this study, higher prevalence rate obtained among HIV-positive participants indicate the higher possibility of coinfection of HSV-2 infection among HIV-positive participants as postulated by Schiffer et al. (2014). The prevalence obtained among participants presenting with fever is higher than reported in Zaria, Nigeria (Aminu et al., 2014). Genital herpes is a life-long incurable infection that causes medical, psychological and social concerns, therefore, these patients might be undergoing some of these concerns.

In this study, the prevalence found among pregnant women is lower than the reported in

\section{REFERENCES}

Adelusi, B. (1977). Sero-epidemiology of herpes type- 2 virus and carcinoma of the cervix in Ibadan. African Journal of Medical Sciences.6(2):95-102.

Agabi, Y.A., Banwat E.B., Mawak J.D., Lar P.M., Dashe N, and Dashen M. (2010).
Port-Harcourt, Nigeria (Okonko et al., 2015). The higher IgG prevalence in this study could be probably due to active sexual life and also pregnancy has been reported as a factor that reactivates HSV-2 from its latent state. This also emphasizes the possible risk of neonatal infection. This could be due to the fact that pregnancy may activate the latent HSV-2 infection and possibly lead to neonatal infection. To our knowledge, no study had estimated the prevalence of HSV-2 among apparently healthy individuals in Nigeria. This shows that many in Nigeria are infected with the virus asymptomatically and it may be because of lack of awareness on its mode of transmission.

The higher prevalence among old age can be explained by the fact that HSV-2 infections persist for life, the prevalence increases with age through the sexually-active years. In line with the present study, studies in Nigeria (Mawak et al., 2012; Kalu et al., 2014) and other countries (Prathiba et al., 2012; Herrera-Ortiz et al., 2013; Amudha et al., 2014) have shown a statistically significant association between HSV-2 infection and age of the participants.

Although in this study there was no statistically significant association observed between gender and HSV-2 prevalence, prevalence was higher in females than males. This disparity between genders could be probably due to of the difference in sample size between males and females or may also reflect anatomical differences in susceptibility to infection and greater efficiency of transmission from men to women as been observed by Bradley et al. (2014).

\section{CONCLUSION}

An overall $72.8 \%$ prevalence rate of antibodies to HSV-2 was obtained in this study. HIV positivity and feverish condition were significantly associated with HSV-2 infection. Of all the sociodemographic factors studied, only marital status was significantly associated with HSV-2 prevalence rate. Similarly, none of the risk factors studied were associated with HSV-2 in the study. However, females (2.02), low socioeconomic (2.01), no sexual activity (1.1), multiple sex partner (1.9), use of protection (1.0), STI (2.3) were more likely to be infected with HSV-2.

Seroprevalence of herpes simplex virus type-2 among patients attending the Sexually Transmitted Infections Clinic in Jos, Nigeria. Journal Infection in Developing Countries, 4(9):572-575.

Akhtar, J. Dashe, N and Shukla, D. (2009). Viral entry mechanisms: cellular and viral 
Special Conference Edition, November, 2019 mediators of herpes simplex virus entry. Federation of European Biochemical Societies Journal, 276(24); 7228-7236.

Aminu, M. Bodam, B.B. and Adams, A.M. (2014). Seroprevalence of HSV-2 among pregnant women and patients presenting with fever at the university health services ABU main campus, Zaria, Nigeria. An oral paper presented at the $49^{\text {th }}$ annual conference of the science association of Nigeria held at university of Ilorin, kwara state from $27^{\text {th }}$ april to $1^{\text {st }}$ may, 2014.

Azodo, C.C., and Umoh, A.O. (2015). Herpes labialis among dental healthcare providers in Nigeria. Indian Journal of Dentistry, 6:116-120.

Barnabas, R.V., Wasserheit, J.N., Huang, Y.D., Janes, H. Morrow, R. Fuchs, J. Mark, K.E., Casapia, M. Mehrotra, D.V., and Buchbinder, S.P. (2011). Impact of Herpes Simplex Virus type 2 on HIV-1 acquisition and progression in an HIV vaccine trial (the step study) Journal of Acquired Immune Deficient Syndrome, 57; 238-244.

Berger J.R., Brooks, C.A., Guinan, M.E., and Houff, S. (2008). Neurological complications of herpes simplex virus type 2 infection. Archives of Neurology, 65(5); 596-600.

Boni, C.C., Zaba, F. Meite, S. Mlan, A. Inwoley, K. Kouassi, M. Bengue, A. Sevede, D. Faye, K.H., and Dosso, M. (2015). Seroprevalence of herpes simplex virus 2 infection among pregnant women in urban health training Yopougon-Attie (Cote D'ivoire). Journal of Medical Laboratory and Diagnosis, 6(3): 17-21.

Bradley, H. Lauri, E. Theda, G. and Geraldine M.M. (2014). Seroprevalence of Herpes Simplex Virus Types 1 and 2-United States, 1999-2010, Journal of Infectious Diseases, 209; 325-333.

Brooks, G.F., Butel, J.F., and Morse, S.A. (2010). Herpesviruses. In Jawetz, Melnick and Adelberg's Medical Microbiology. 25th edition. USA: McGraw-Hill Companies, Inc, 45; 433-455.

Centers for Disease Control and Prevention, (2012). STD Curriculum for Clinical Educators. Genital Herpes simplex virus (HSV). Department of Health and Human Services, November CDC MMWR Morb Wkly., 7-36

Centers for disease Control and Prevention, National Center for HIV/AIDS, Viral Hepatitis, STD, and TB Prevention, Division of STD Prevention (2013).
Sexually transmitted diseases: Genital Herpes-CDCFact Sheet.

Clara, A.S., Astrid, M. Bedoyab, C. Sara, P. Armando, B.C., Angela, M. Gaviriab, E. Carlos, A.R., and Sanchezb, G.I. (2011). Prevalence of specific herpes simplex virus-2 antibodies and associated factors in women of a rural town of Colombia. Royal Society of Tropical Medicine and Hygiene, 2(11): 7-9.

Corey, L. and Wald, A. (2009). "Maternal and Neonatal HSV Infections". New England Journal of Medicine, 361(14); 13761385.

Dada, A.J., Ajayi, A.O., and Diamondstone, L. (1998). A sero-survey of Haemophilis ducreyi, Syphilis, and herpes Simplex Virus type-2 and their association with HIV among workers in Lagos, Nigeria. Sexually Transmitted Diseases, 25; 237-242.

Dauda, U. Gulumbe, S.U., Yakubu, M. and Ibrahim L.K. (2011). Monetering of Infectious Diseases in Katsina and Daura Zones of Katsina State: A Clustering Analysis. Nigerian Journal of Basic and Applied Science, 19(1); 31-42.

De Baetselier, I. Menten, J. Cuylaerts, V. Ahmed, K. Deese, J. and Van Damme, L. (2015). Prevalence and Incidence Estimation of HSV-2 by Two IgG ELISA Methods among South African Women at High Risk of HIV. Advance Virology, 10(3):1-7.

Dellar, R.C., Dlamini, S. and Abdool Karim, Q. (2015). Adolescent girls and young women: key populations for HIV epidemic control. Journal of the International Acquired Immuno Deficiency Syndrome Society, 18(1):1940.

Duru, C.B., Emele F.E., Nnebue C.C., Adinma E.D., Ifeadike G.O., Amilo G.I., Oluboyo A.O., and Oluboyo B.O. (2014) ; Seroprevalence and Co-Existence of Chlamydia Trachomatis and Herpes Simplex Virus Antibodies among Students in a Tertiary Institution. International Journal of Medicine and Medical Sciences, 1(8); 122-130.

Edith, N.J., Kambugu, F. Wasubire, J. Kimeze, J. Robert, S. Albert, J.M., Rimm, A. and Whalen, C. (2014). Seroprevalence of Herpes Simplex Type 2 virus (HSV-2) and HIV infection in Kampala, Uganda. Journal of African Health Sciences, 14(4):782-789. 
Special Conference Edition, November, 2019 FGN, (2007). Legal Notice on Publication of the 2006 Census Report. Federal Government of Nigeria official Gazette, 4 (94); 1-8.

Hadeel, E. Ahmed, I. and Ibrahim, E.W. (2015). Seroprevalence of herpes simplex virus type -2 among pregnant women attending Ibrahim Malik Teaching Hospital, Khartoum state, Sudan. American Journal of Research Communication, 3 (11): 2325-4076.

Kahsay, A.G., Daba, F. Kelbore, A.G., and Sefonias, G. (2015). Prevalence and Associated Factors of Sexually Transmitted Infections Based on the Syndromic Approach among HIV Patients in ART Clinic; Ayder Referral Hospital, Northern Ethiopia. Clinical Medicine Research, 4(5): 132-138.

Kalu, E.I., Mawak, J.D., and Dashe, N. (2014). Seroprevalence of Herpes Simplex Virus Infections among Pregnant Women Attending Antenatal Clinic in Benin, Nigeria: International Journal of Tropical Disease and Health, 4(1); 70-81.

Kimberlin, D.W. (2007). Herpes simplex virus infections of the newborn. Seminars on perinatal, 31(1); 19-25.

Kriebs, I.M. (2008). Understanding Herpes simplex virus: Transmission, Diagnosis and considerations in pregnancy management. Midwifery Womens Health, 53(3);202-208.

Lebrun-Vignes, B. Bouzamondo, A. Dupuy, A. Guillaume J.C., Lechat, P. and Chosidow, O. A. (2007). Meta-analysis to assess the efficacy of oral antiviral treatment to prevent genital herpes outbreaks. Journal of American Academics Dermatology, 57(2); 238-46.

Looker, K.J., Garnett G.P., and Schmid G.P, (2008). An estimate of the global prevalence and incidence of herpes simplex virus type 2 infection. Bull World Health Organization, 86(10); 737-816.

Martin, E.T., Krantz, E. Gottlieb S.L., Magaret A.S., Langenberg A, and Stanberry L. (2009) A pooled analysis of the effect of condoms in preventing HSV-2 acquisition. Archived International Medicine, 169(13); 1233-1240.

Mawak, J.D., Dashe, N. Atseye, A B., and Agabi, Y.A. (2012). Seroprevalence and CoInfection of Herpes Simplex Virus Type 2 and Human Immunodeficiency Virus in Nigeria. Shiraz E-Medical Journal, 13(1); 3-7.

Montefiore, D, Sogbetun, A.O., and Anong, C.N. (1980). Herpesvirus hominis type 2 infection in Ibadan. Problem of nonvenereal transmission. British Journal of Venereum Diseases. 56(1):49-53.

Ojinmah, U.R., Nnoruka, E.N., Ozoh, G.A., Onyekonwu, C.L., and Aguwa, E.N. (2012). Herpes simplex virus type 2 infection among females in Enugu, Enugu State. Shiraz E-Medical Journal, 13(1); 5-9.

Okonko, I.O., Cookey, T.I., and Cookey, T.I. (2015). Seropositivity and determinants of immunoglobulin-G (IgG) antibodies against Herpes simplex virus (HSV) types -1 and -2 in pregnant women in Port Harcourt, Nigeria. African Health Science, 15(3):737-47.

Phipps, W, Engels, M, and Senn, C. (2015). HSV2 shedding common among Africans regardless of HIV infection Journal Infection Diseases, 20(3): 123-127.

Rathore, S. Jamwal, A. and Gupta V. (2010). Herpes simplex virus type 2: Seroprevalence in antenatal women. Indian Journal of Sexually Transmited Diseases and Aquired Immune Deficiency Syndrom, 31(4); 11-15.

Sarmukaddam, S.S., and Gerald, S.G. (2006). Validity of assumptions while determining sample size. Indian Journal of Community Medicine, 29(20); 20042006.

Schiffer, J.T., Mayer. B.T., Fong Y, Swan D.A., and Wald A. (2014). "Herpes simplex virus-2 transmission probability estimates based on quantity of viral shedding". Journal of Interface, 11(95); 26-34.

Shannon, B. Joon Yi, T. Jamie, T.P., Lisungu, C. Praseedha, J. Megan, S. Wangari, T. Sanja, H. Robert, R. and Rupert, K. (2015). Impact of Asymptomatic Herpes Simplex Virus Type 2 Infection on Mucosal Homing and Immune Cell Subsets in the Blood and Female Genital Tract. The Journal of Immunology. 192:5074-5082.

Stanberry, L.R., Cunningham, A.L., Mindel, A. Scott L.L., Pruance S.L., and Aoki, F.Y. (2000). Prospects for control of herpes simplex virus disease through immunization. Clinical Infectious Disease, 30; 549-566.

Tobian, A.A., Charvat, B. Ssempijja, V. Kigozi, G. Serwadda, D. and Makumbi, F. (2009). Factors associated with the prevalence and incidence of herpes simplex virus type 2 infections among men in Rakai, Uganda. Journal of Infectious Diseases, 199; 945-949. 
Special Conference Edition, November, 2019

Tronstein, E. Johnston, C. Huang M.L., Selke, S. Magaret, A. and Warren, T. (2011). Genital shedding of herpes simplex virus among symptomatic and asymptomatic persons with HSV-2 infection. Journal of the American Medical Association, 305(14); 1441-1449.

Tyler, K.L. (2004). Herpes simplex virus infections of the central nervous system: encephalitis and meningitis including Mollaret's. Herpes, 12; 1157-1164.
Wald, A. (2008). Risk of human immunodeficiency virus infection in herpes simplex virus type-2 seropositive persons: a meta-analysis. Journal of Infectious Disease, 185; 45-52.

World Health Organization (2015): Globally, an estimated two-thirds of the population under 50 are infected Herpes Simplex Virus Type-2. Geneva, Switzerland. WHO; 2015.

Avialable:www.who.int/hiv/pub/sti/who_ hiv_aids_January, 2015). 